\section{International Scientific Journal Theoretical \& Applied Science}

Natalia Vladimirovna Batciun

Associate Professor,

Department of World Economy,

Irkutsk National Research Technical University,

Russia

nbatsun@mail.ru

Year: 2015 Issue: 04 Volume: 24

Published: $30.04 .2015 \quad$ http://T-Science.org

SECTION 31. Economic research, finance,

innovation, risk management.

\title{
PROSPECTS AND DYNAMICS OF DEVELOPMENT OF AN OIL AND GAS COMPLEX OF EASTERN SIBERIA: ECONOMY AND ECOLOGY
}

\author{
Abstract: The huge number of reserves of natural gas and oil in the territory of Eastern Siberia at the same \\ time is a source as economic wellbeing, and a source of environmental problems \\ Key words: reserves of gas and oil, geological works, Eastern Siberia, expected resources, oil and gas \\ potential, economic growth of the region, environmental problems. \\ Language: Russian \\ Citation: Batciun NV (2015) PROSPECTS AND DYNAMICS OF DEVELOPMENT OF AN OIL AND GAS \\ COMPLEX OF EASTERN SIBERIA: ECONOMY AND ECOLOGY. ISJ Theoretical \& Applied Science 04 (24): \\ 208-212. \\ Soi: http://s-o-i.org/1.1/TAS*04(24)36 Doi: crossef http://dx.doi.org/10.15863/TAS.2015.04.24.36
}

\section{ПЕРСПЕКТИВЫ И ДИНАМИКА РАЗВИТИЯ НЕФТЕГАЗОВОГО КОМПЛЕКСА ВОСТОЧНОЙ СИБИРИ: ЭКОНОМИКА И ЭКОЛОГИЯ}

Аннотация: Огромное количество запасов природного газа и нефти на территории Восточной Сибири одновременно является источником как экономического благополучия, так и источником экологических проблем.

Ключевые слова: запасы газа и нефти, геологические работы, Восточная Сибирь, прогнозные ресурсы, нефтегазовый потенциал, экономический рост региона, экологические проблемы.

На территории России сосредоточено огромное количество запасов природного газа и нефти. Одним из перспективных регионов газодобычи считаются недра Восточной Сибири. Результаты геологоразведочных и научноисследовательских работ позволили оценить перспективы нефтегазоносности Сибирской платформы и доказать её перспективность в использовании.

Общий мировой разведанный запас по природному газу оценивается в 500-550 трлн куб. м, по нефти - в 200-300 млрд т. [1].

Недра Восточной Сибири имеют высокий потенциал, однако в условиях низкой степени их разведанности для привлечения недропользователей в регион, нужна поддержка со стороны государства [2]. Результаты геологоразведочных и научноисследовательских работ позволяют оценить перспективы нефтегазоносности Сибирской платформы как высокие. Установлено, что в пределы Иркутской области из соседней Якутии широкой полосой заходит нефтегазовый горизонт с глубоким залеганием пластов. Значительная часть территории Иркутской области (около 450 тыс. кв. км) располагается на Сибирской платформе, а значит тоже имеет большие перспективы на выявление новых месторождений нефти и газа. В пределы области вклинивается обширная Лено-Тунгусская нефтегазоносная провинция, которая разделяется на четыре крупные нефтегазоносные области - НепскоБотуобинскую, Ангаро-Ленскую, ПрисаяноЕнисейскую и Прибайкало-Патомскую.

Обширная территория Иркутской области пока слабо изучена глубоким бурением. Тем не менее, уже открыто свыше десятка месторождений, большинство из которых является комплексными: содержат нефть, газ и конденсат. Прогнозный потенциал Иркутской области разведан не более чем на $10-13 \%$ и вероятность открытия новых нефтегазоносных месторождений достаточно высока[1]. Нефть месторождений Иркутской области, как и всей 
Сибирской платформы, отличается специфическими качествами. Она легче (плотность 0,8 г/см куб.) западносибирской, что повышает выход легких фракций при ее переработке; малосернистая $(0,12$ процентов серы) и малопарафинистая (около 1 процента парафинов), что облегчает ее транспортировку по нефтепроводу до потребителя. Запасы газа на открытых месторождения оцениваются по категориям $\mathrm{C} 1+\mathrm{C} 2$ в 1,2 трлн куб. м, что также составляет 10-15 процентов потенциальных ресурсов Иркутской области. Россия занимает первое место по запасам природного газа в мире в РФ находится 24,4 проц всех мировых запасов, или 49,541 трлн кубометров. Об этом говорится в ежегодном докладе World Oil and Gas Review, подготовленном итальянской энергетической компанией Eni [2].

O нефтегазовом потенциале Восточной Сибири и Иркутской области в частности речь ведётся давно. В регионе с каждым годом увеличивается объём добычи углеводородного сырья, нефть с иркутских месторождений поступает в трубопровод ВСТО («Восточная Сибирь - Тихий океан»), обсуждаются планы по строительству газотранспортной системы. Но нельзя забывать, что добыче нефти или газа и поставке УВС в трубопроводные системы предшествует долгая, требующая значительных вложений и связанная со многими рисками работа - от получения лицензии на участок недр до его изучения, оценки и постановки запасов на государственный баланс [3]. Несмотря на накопленные архивные данные, единой картины нефтегазового потенциала региона нет.
В Иркутской области разведаны участки вдоль ВСТО, нефтепровод, проходящий от г. Тайшет Иркутской области до нефтеналивного порта Козьмино в заливе Находка и соединяет месторождения Западной и Восточной Сибири с рынками Азии и США, протяженность около 4 740 км). Севернее трубопровода очень много «белых пятен», недостаточно разведано и Предбайкалье - Качугский, Жигаловский районы . Самое главное в недропользовании на этапе разведки - это экономика. Чтобы частный бизнес пошёл в разведку, он должен быть уверен в рентабельности. Поэтому поддержка со стороны государства необходима. Если недропользователь идёт в малоизученный район, необходимы лояльный подход к срокам ГРР (геологоразведочных работ), помощь в строительстве инфраструктуры, снижение стартового размера разового платежа или предоставление налоговых льгот. По данным Иркутскнедра, на поисковые работы государство ежегодно направляет около 1 млрд рублей, кроме того свои средства вкладывают недропользователи [2]. Однако более половины лицензий на УВС в Приангарье принадлежит мелким предприятиям, которые не справляются с выполнением лицензионных соглашений. Поэтому часть участков в перспективе может вернуться в нераспределённый фонд. В недалеком будущем следует ждать активной работы по освоению новых месторождений Восточной Сибири, а так же существенное увеличение добычи нефти и газа на территориях, подготовленных к промышленной эксплуатации.

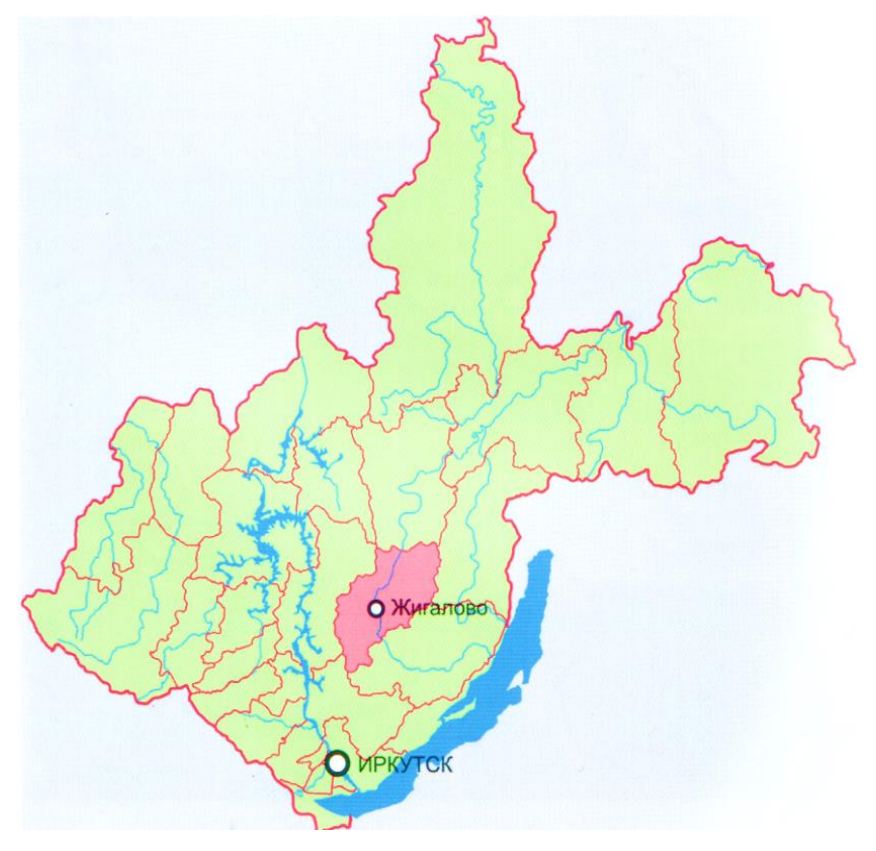

Рисунок 1 - Карта Иркутской области.

ISPC The Combination of Technology \&

Education, Östersund, Sweden 
Качество и объем прогнозных ресурсов полезных ископаемых, выявленных в регионе, обеспечивают возможность эффективного проведения геологоразведочных работ на дефицитные и высоколиквидные виды минерального сырья. Включение их в хозяйственный оборот позволит не только поддерживать и развивать достигнутые ранее мощности действующих добывающих производств, но и обеспечить создание новых крупных предприятий, как по добыче, так и по переработке минерального сырья. Одним из перспективных районов развития является Жигаловский район (рис.1). Он расположен в восточной, Приленской части Иркутской области, находится за пределами зоны интенсивного заселения и освоения и не располагает удобными коммуникациями. Территория характеризуется низким уровнем социально-экономического развития, численность населения неуклонно снижается, что связано с естественной убылью населения и оттока наиболее активной части жителей из-за отсутствия необходимого числа рабочих мест, неустроенности быта. Этот регион обладает колоссальными запасами природноминерального сырья. Перспективы экономического роста этого региона связываются в основном с освоением Ковыктинского газоконденсатного месторождения. Газоразведка геологических площадок даже с небольшой долей эксплуатации приносит достаточно неплохие прибыли, значит, промышленное освоение месторождений углеводородного сырья должно положительно сказаться на будущем Жигаловского района и будет способствовать экономическому развитию, что приведет к снижению уровня безработицы [4]. Район является одним из малонаселенных в области, численность населения составляет 10,0 тысяч человек, территория относится к редкозаселенному типу с низкой плотностью

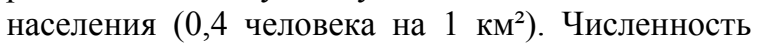
населения неуклонно снижается, что связано с естественной убылью населения и оттоком наиболее активной части жителей. Регион характеризуется низким уровнем социальноэкономического развития и, по сути, является экономически депрессивным. Наибольшую экономическую ценность представляют Знаменское месторождение гидроминерального сырья и Ковыктинское газоконденсатное месторождение. Именно с ним связывают будущее Жигаловского района. Ковыктинское месторождение (Ковыкта) - перспективное газоконденсатное месторождение в Иркутской области. Расположено в необжитой местности на востоке региона, в 450 километрах к северо- востоку от Иркутска, на территории Жигаловского и Казачинско-Ленского районов. Запасы природного газа на месторождении оцениваются в 1,5 триллиона кубометров газа, 2,3 миллиарда кубометров гелия и 115 миллионов тонн жидкого газового конденсата. Активы компании и лицензия на разработку в 2011 году были приобретены «Газпромом». По последним данным, «Газпром» рассчитывает ввести Ковыкту в эксплуатацию в 2024 году [4].

Строительство трубопровода по маршруту Ковыкта - Ангарск может быть осуществлено при экономической эффективности проекта, достичь которую можно при трёх условиях: государственная поддержка в виде налоговых преференций, начало полномасштабного освоения Ковыктинского ГКМ (газоконденсатное месторождение), а также строительство инфраструктуры за счёт федерального или регионального бюджетов[5].

Дополнительно к магистральному газопроводу могут быть проложены ответвления для поставки газа на рынки близлежащих регионов. Проект предполагает два вида использования газа: в нефтехимической промышленности в качестве сырья и в коммунальной энергетике в качестве альтернативного топлива. Оба направления газификации Иркутской области предусматривают создание дополнительных рабочих мест, ведь потребуются строители трубопровода, рабочие на новых нефтехимических производствах и др. Кроме того, газификация предполагает развитие инфраструктуры: транспорт, связь, сфера услуг. [6]

Невозможно оставить в стороне и экологическую сторону деятельности. Большое значение имеет то, что экологическая политика «Газпрома» является приоритетной для компании. Она является основой для определения экологической стратегии компании, целевого планирования ее деятельности в сфере экологии на краткосрочный и среднесрочный период. Реализация экологической политики будет осуществляться посредством закрепления в договорах с подрядчиками и поставщиками компании обязательств в области охраны окружающей среды в регионах, в которых предполагается осуществление деятельности компании[7].

Учитывая неизбежные техногенные факторы, относящиеся к освоению месторождения, возможно составить прогноз экологических последствий для Жигаловского 
района. Освоение месторождения окажет огромное влияние на природные комплексы верхнееленских районов. В первую очередь оно выразится в строительстве дорог, в отчуждении и сведении лесов под буровые, под вертолетные площадки, под строительство ЛЭП, под газопроводы, под промплощадки и под вахтовые поселки. Будет прямое влияние сооружений и промплощадок на лесные массивы (утечка газа, нефтепродуктов и других вредных веществ), влияние атмосферных выбросов. Грунтовые воды, питающие реки, окажутся загрязненными буровыми растворами, содержащими различные соли и измельченную породу, нефтепродуктами и перенасыщенными рассолами из пластов с высоким давлением. Загрязнение воздуха заметнее всего подействует на темнохвойные леса. Начнутся усыхание и ветровалы деревьев, замещение зимнезеленых растений (например, брусничника) летнезелеными травами. Из-за многочисленных вырубок под полог леса будет попадать больше солнечного света, что нарушит обычное сезонное «расписание» таяния и промерзания почв [9].

При условии соблюдения экологической безопасности, с началом освоения месторождений углеводородного сырья перед районом открываются новые экономические и социальные перспективы не только Жигаловского района, но Иркутской области в целом. Существует несколько основных проблем нефтеперерабатывающих производств. Специфика производимой продукции требует определенных ограничений на пути загрязнения окружающей среды. Большинство получаемых продуктов имеют низкую плотность и высокую испаряемость, что в свою очередь приводить к особенно сильному загрязнению воздуха и почв [8]. Разливы и утечки различных нефтепродуктов на протяжении десятилетий на одной и той же территории привели к тому, что почва на многие метры под территорией НПЗ пропитана смесью углеводородов. В некоторых местах из-за особенностей строения пород образовались так называемые «линзы», скопления жидких углеводородов в полостях пород, для них непроницаемых. Основные выбросы в атмосферу связаны с процессами сжигания топлива в технологических печах и на факелах, с неорганизованными выбросами от очистных сооружений, с выбросами при производстве, хранении и отгрузке готовой продукции и т.д.

Разумеется, сжигаемые фракции проходят предварительную очистку, но полностью удалить нежелательные компоненты невозможно. Согласно действующей в настоящее время в России статической отчетности к топливноэнергетическому комплексу (ТЭК) относятся: добыча топливно- энергетических ресурсов, и производство и распределение электроэнергии, газа и воды. По данным видам деятельности и оценен вклад ТЭК в воздействие на элементы природной среды. В целом по Байкальскому региону вклад ТЭК в выбросы загрязняющих веществ в атмосферу оценивается в $60 \%$, в сброс загрязненных стоков в водные объекты - $27 \%$ и образование отходов - $42 \%$. За основу перспективной экологической оценки вклада топливно-энергетического комплекса приняты перспективные топливно-энергетические балансы, разработанные на базе программ социально-экономического развития исследуемых территорий. [10].

References:

1. (2012) «Nauka v Sibiri», ezhenedelnaya gazeta sibirskogo otdeleniya rossijskoj akademii nauk - vypusk №2137 ot 10.07.2012.

2. (2014) «Sibirskij energetik», izdatelskaya gruppa Vostochno-Sibirskaya pravda - vypusk № 353 ot 4.04.2014.

3. (2014) «Prajm», agenstvo ekonomicheskoj informacii - izdanie ot 18.09.2014.

4. Vinokurov Mixail Flekseevich (2010) Zhigalovskij rajon : [nauch.-populyar. i ucheb.sprav. izd.] / M. A. Vinokurov, A. P. Suxodolov ; M-vo obrazovaniya i nauki RF, Bajkal. gos. un-t ekonomiki i prava. - Irkutsk : izd-vo BGUEP, 2010.
5. (2015) Gazprom: Stroitel'stvo gazoprovoda s Kovykty na yug Priangar'ya ekonomicheski neobosnovanno.

Available:

http://news.ircity.ru/2460/

(Accessed: 25.04.2015).

6. (2006) Strategii socialno-ekonomicheskogo razvitiya obedinennoj Irkutskoj oblasti na period do 2010 i na perspektivu do 2020 goda. Available:

http://polit.ru/article/2006/05/22/irkstrategy/ (Accessed: 25.04.2015).

7. (2015) Ekologicheskaya politika «Gazprom». Available: 
Impact Factor ISRA (India) $\quad=\mathbf{1 . 3 4 4}$

Impact Factor ISI (Dubai, UAE) $=\mathbf{0 . 8 2 9}$

based on International Citation Report (ICR)

Impact Factor GIF (Australia) $\quad \mathbf{0} \mathbf{0 . 3 5 6}$

http://www.gazprom.ru/nature/ecology/

(Accessed: 25.04.2015).

8. Manovyan AK (2001) Texnologiya pervichnoj pererabotki nefti i prirodnogo gaza. Ucheb. posobie dlya vuzov. - 2-e izd. - Moscow: Ximiya, 2001.

9. Abrosimov AA (2000) Socialnoekologicheskie problemy neftepererabotki : $\begin{array}{lr}\text { Impact Factor JIF } & =\mathbf{1 . 5 0 0} \\ \text { Impact Factor SIS }(\text { USA) } & =\mathbf{0 . 9 1 2} \\ \text { Impact Factor PИНЦ (Russia) } & =\mathbf{0 . 1 7 9} \\ \text { Impact Factor ESJI }(\text { KZ }) & =\mathbf{1 . 0 4 2}\end{array}$

ekologicheskaya bezopasnost. A.A. Abrosimov. Ekologiya i promyshlennost Rossii. - 2000. №11.

10. (2014) Gosudarstvennyj doklad «O sostoyanii i ob oxrane okruzhayushhej sredy Irkutskoj oblasti v 2013 godu». - Irkutsk: Izdatelstvo Instituta geografii im. V.B. Sochavy so ran, 2014 